\title{
Kenaikan Harga Bahan Bakar Minyak (BBM) Atas Nama Rakyat (Tinjauan Kritis Konsepsi Keadilan Sosial Ekonomi Ibnu Taimiyah)
}

\author{
Arin Setiyowati \\ Universitas Muhammadiyah Surabaya, Fakultas Agama Islam, Prodi Perbankan Syariah \\ Jl. Raya Sutorejo No.59, Dukuh Sutorejo, Mulyorejo, Kota SBY, Jawa Timur 60113 \\ Email:arin.st@fai.um-surabaya.ac.id
}

\begin{abstract}
The continue phenomenon of fuel prices increasing in Indonesia are always both between the two sides (there are government and community). Debating the agree side and disagree side of being the main contents of the escort policies. But we know the socio-economics condition of 'tragic' Indonesia be raised expenditures greater than revenues, while expenditure was only focused on subsidies of energy which unfortunately more widely used by the upper middle class society rather than small communities. Besides external factors that affect the pattern of the domestic politics of oil policy. In the position of the economic dilemma, the government apllying the economic logic of "Pareto Optimum ", it's mean that the transfering of enjoyment to be fair, but it isn't only focusing only on short-term policies, but also followed by reconstruction the quality of sustainable development. And Ibn Taimiyyah as one of the Islamic Economic Thinkers, which one of the legacy of the socio- economic justice concept to be analysis study and be the counter of the phenomenon of rising fuel prices and Compensation Package, as well as to macroeconomic conditions in Indonesia.
\end{abstract}

Keywords: Oil Politics, the rising prices of fuel and fuel subsidies, fuel compensation package, The Conception of Socio-Economic Justice from Ibn Taimiyyah.

\begin{abstract}
Abstrak
Fenomena rutinistas Kenaikan harga BBM di Indonesia selalu membenturkan antara dua kubu (Pemerintah dan masyarakat). Perdebatan pro dan kontra menjadi isi utama pengawalan kebijakan tersebut. Namun melihat kondisi sosial ekonomi Indonesia 'tragis' dimunculkan pengeluaran yang lebih besar daripada pendapatan, sementara pengeluarannya itu hanya terfokus pada subsidi energi yang sayangnya lagi lebih banyak dimanfaatkan oleh masyarakat golongan menengah ke atas daripada masyarakat kecil. Selain dipicu oleh faktor eksternal yang mempengaruhi pola politik kebijakan minyak dalam negeri. Dalam posisi dilema ekonomi tersebut, logika ekonomi yang dipakai pemerintah adalah "Pareto Optimum", artinya transfer kenikmatan supaya adil, namun hal tersebut tidak diikuti oleh rekonstruksi pembangunan berkualitas yang berkelanjutan, hanya fokus pada kebijakan jangka pendek. Dan Ibnu Taimiyah sebagai salah satu Pemikir Ekonomi Islam, yang mana salah satu warisannya berupa konsep keadilan sosial ekonomi layak dijadikan pisau analisa sembari kounter atas fenomena kenaikan BBM dan Paket Kompensasinya, maupun untuk kondisi perekonomian makro di Indonesia.
\end{abstract}

Kata Kunci: Politik Minyak, Kenaikan harga dan Subsidi BBM, Paket Kompensasi BBM, Konsepsi Keadilan Sosial Ekonomi Ibnu Taimiyah.

\section{PENDAHULUAN}

Indonesia menjadi langganan perdebatan pro-kontra kenaikan harga BBM dalam rangka pemotongan subsidi BBM, yang mana dengan dalih untuk dialokasikan untuk bantuan tunai langsung (BLT) atau bantuan langsung sosial masyarakat (BLSM), beasiswa, biaya kesehatan dan sosial lainnya.

Jika kritis dalam memaknai setiap fenomena, maka hal ini bukan barang baru lagi dalam perjalanan perekonomian Indonesia terkait fenomena kenaikan harga BBM. 
Berawal dari pemerintahan Indonesia pasca kemerdekaan yakni saat rezim orde lama (1959-1966). Dan tidak jauh berbeda, di rezim Orde Baru pun tidak bisa menghindarkan negara dari penyakit defisit APBN. Kedua rezim berada pada latar ekonomi yang sama, saat krisis gencar melanda, sementara letak perbedaannya terletak pada perkembangan cara penyelesaiannya. Yang mana di rezim orde lama percetakan uang tanpa diikuti peningkatan jumlah produksi barang menjadikan inflasi berlebih. Seperti halnya orde baru, hanya saja di era ini mengundang bantuan asing yang lagi-lagi sama tanpa diimbangi peningkatan produksi barang dan jasa, sehingga sama halnya dengan menggali lubang kuburan untuk negeri sendiri dengan jeratan hutang tersebut. (Mubyarto dkk,2005)

Berangkat dari data rutinitas kebijakan kenaikan harga BBM dalam alur perekonomian Indonesia, maka perlu diketahui juga terkait kronologis momentum pemberian subsidi hadir di Indonasia, yang mana hal ini pun tidak lepas dari proses jatuh bangunnya perekonomian negara. Sejarah pembengkakan subsidi dapat dilihat pada tahun 1972/1973 dari penjualan BBM pemerintah masih mendapat laba sebesar Rp 31 milyar dan meningkat pada tahun 1973/1974 sebesar Rp 34,2 milyar. Tahun 1975/1976 jumlah subsidi baru sebesar Rp 1,3 milyar dan selama setahun 1979/1980 subsidi mencapai Rp 535 milyar. Rekor paling akhir selama kurun waktu itu terjadi di tahun 1981/1982 yaotu sebesar Rp 1.511 milyar. Subsidi kemudian menurun lagi hingga $\mathrm{Rp}$ 924 milyar di tahun 1982/1983. Pada tahun 1999/2000 telah mencapai 30 trilyun. Pada tahun 2004 pemerintah mengumumkan defisit anggaran dalam APBN telah membengkak menjadi 32,9 trilyun. Angka tersebut setara dengan $122,54 \%$ dari besarnya defisit yang ditargetkan pemerintah dan DPR, yakni sebesar 26,27 trilyun. Pembengkakan defisit tersebut merupakan akibat dari membengkaknya subsidi BBM yang juga merupakan akibat dari akumulasi peningkatan harga minyak dunia. (Hasyim, 2005).

Dengan berbasis data dari Kemenkeu RI (Data Pokok APBN 2007-2013), dijelaskan bahwa Penerimaan negara dari bukan pajak dari sektor migas terhitung masih mendominasi, walaupun fluktuasi dari tahun ke tahun kadar penerimaan tersebut menurun ( PNBK Migas (2007-2013 : (2007) 124.783,7 ; (2008) 211.617,0 ; (2009) 125.752,0 ; (2010) 152.733,2 ; (2011) $193.490,6$; (2012) 198.311,1 ; (2013) 174.868,5). Namun, hal inipun sebanding dengan jumlah belanja Pemerintah dalam hal sektor migas (bersubsidi) juga mendominasi anggaran belanja negara. Hal ini tentu tidak lepas dari faktor kedudukan kritis minyak dalam keseimbangan energi dunia serta ketidakmerataan distribusi sumber-sumbernya, membuat minyak tampil sebagai satu jenis komoditi yang baik secara ekonomis, politis bahkan strategis sedemikian pentingnya. Politik penentuan harga dan kendali pengadaannya seringkali menjadi sumber ketegangan internasional yang begitu eksplosif.

Singkatnya minyak mempunyai satu hubungan fungsional dengan berbagai isu penting dalam tertib kehidupan umat manusia. Untuk mempertegas pernyataan tersebut, juga bisa dikatakan bahwa minyak berkaitan secara sistematis dengan sejumlah masalah penting seperti dengan derajat pertumbuhan ekonomi, tingkat pengangguran, inflasi, kebijaksanaan perdagangan dan orientasi kebijaksanaan politik luar negeri secara umum. Ia tidak dapat dipisahkan dari persoalan kohesi politik dalam satu persekutuan atau blok politik internasional tertentu dan pembangunan ekonomi di semua negara. (Qystein Noreng, 1983)

Konsekuensinya segala persoalan yang bersangkut paut dengan minyak pasti memiliki satu prioritas tinggi dalam industri, ekonomi, perdagangan, dan kebijaksanaan politik luar negeri, baik di negara importir maupun eksportir sendiri, tak peduli apakah negara itu sudah tergolong maju apalagi negara berkembang.

Ditambah lagi, alokasi subsidi BBM mengangkangi untuk subsidi non-energi lainnya misalnya subsidi listrik, pangan, pupuk, benih, kedelai, pajak, kredit program, kewajiban pelayanan umum (public service obligation/PSO) dan sebagainya. Dengan berbasis dari sumber data yang sama, satu hal menjadi keganjalan adalah ketika Pemerintah gencar menyuarakan bahwa kenaikan harga BBM dimaksudkan untuk realokasi dana pada sektor sosial dan pendidikan. 
Jika ditarik benang merah terhadap kondisi kekinian, fenomena kenaikan harga BBM yang otomatis diiukuti penyunatan subsidi BBM ini tidak lepas dari pro-kontra, yang mana tidak keluar pula dari payung konstelasi perpolitikan ekonomi bangsa. Bukan sekedar ikut arus, namun perlu ditelisik data-data faktual yang mampu disuguhkan dari masingmasing kubu sehingga bisa mengurai virus politisasi yang merusak proses ber-keadilan sosial ekonoim bagi seluruh rakyat Indonesia.

Berdasarkan data dari tim sosialisasi penyesuaian subsidi bahan bakar minyak (Bersama-Sama Selamatkan Uang Bangsa, 2013), harga minyak dunia yang stabil tinggi, di atas US $\$ 100$ per barel, dan konsumsi BBM di dalam negeri yang semakin melonjak tinggi belakangan ini membuat subsidi untuk Premium dan Solar menjadi semakin besar. Dalam menghitung Anggaran Pendapatan dan Belanja Negara (APBN) 2013, Pemerintah dan DPR menyepakati harga minyak mentah Indonesia sebesar US\$100,0 per barel sebagai patokan. Kenyataannya, selama triwulan I rata-rata harga minyak mentah Indonesia saat ini sudah US\$111,12 per barel. Sedangkan konsumsi Premium dan Solar juga meningkat dari 41,8 miliar liter pada 2011 menjadi 45,0 miliar liter pada 2012 lalu.

Tahun ini, konsumsi BBM bersubsidi di dalam negeri diperkirakan akan naik lagi menjadi hampir 50 miliar liter. Akibatnya, subsidi untuk Solar dan Premium sepanjang 2013 akan melonjak dari Rp 193,8 triliun menjadi Rp 251,6 triliun. Jika harga minyak dunia tetap tinggi dan konsumsi terus seperti ini, subsidi akan menggelembung di luar kemampuan anggaran negara untuk memikulnya.

Yang perlu ditegaskan lagi di sini bahwa Indonesia bukanlah negara penghasil minyak seperti era tahun 1970-an. Artinya, minyak yang dihasilkan dari perut Indonesia sekarang ini sudah tidak cukup untuk memenuhi kebutuhan dalam negeri. Untuk menutup kekurangan tersebut Indonesia harus mengimpor minyak mentah untuk diolah di kilang dalam negeri maupun berupa produk jadi dalam bentuk BBM. Secara netto, Indonesia adalah pengimpor minyak.

Memang seiring dengan kenaikan harga minyak, ada kenaikan penerimaan negara.
Namun, pada saat yang sama pengeluaran negara juga turut melonjak. Naiknya pengeluaran itu jauh lebih tinggi dibandingkan dengan tambahan pendapatannya. Jadi secara netto, kenaikan harga minyak justru berefek negatif, memberikan beban tambahan pada anggaran negara. Defisit anggaran semakin besar karenanya. Penerimaan negara dari minyak dan gas saat ini semakin kecil karena produksi dalam negeri semakin menurun (Menurut data kementrian ESDM, pada tahun 2008 lalu produksi minyak kita masih 977 ribu barel per hari dengan konsumsi BBM bersubsidi sebesar 39,18 miliar per liter per tahun. Pada tahun 2012 lalu, produksi minyak sudah turun menjadi 860 ribu barel per hari sementara konsumsi BBM bersubsidi, termasuk minyak tanah, malah naik dengan tajam menjadi di atas 45,07 miliar liter per tahun). Di sisi lain, subsidi BBM justru makin maningkat kerena konsumsi semakin besar. Tak boleh dilupakan, harga jual premium dan solar juga tidak berubah selama hampir lima tahun terakhir, sejak kenaikan harga yang terakhir 2008.

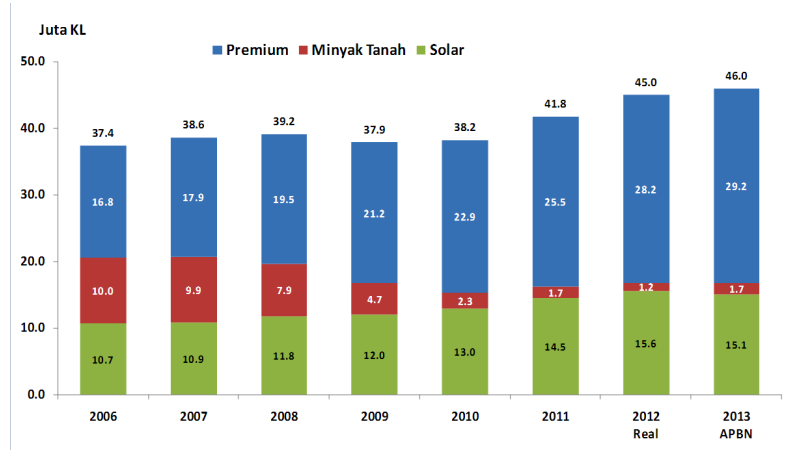

Grafik 1.1. Konsumsi BBM Bersubsidi

Konsumsi premium bersubsidi selama tiga tahun terakhir rata-rata meningkat sebesar 10,1\% dan solar sebesar 9,1\%.

Sumber : Kementrian Keuangan

Melihat kondisi tersebut, logika ekonomi yang dipakai pemerintah bahwa ketika harga minyak mentah dunia meningkat, maka subsidi BBM pun semakin menggelembung dan menyebabkan APBN membengkak, alhasil defisit anggaran yang lagi-lagi harus ditanggung rakyat. Walaupun kondisi perekonomian Indonesia tumbuh di atas 6\% dalam empat tahun terakhir. Tak heran jika konsumsi minyak di dalam negeri melonjak. 
Sungguh tidak sehat jika Pemerintah terus menuruti saja permintaan kenaikan subsidi dari kalangan yang sudah mampu. Pemerintah tentu harus memberikan subsidi kepada yang lebih berhak, bukan subsidi berupa BBM yang murah.

Dengan kenaikan harga BBM artinya penyusutan subsidi BBM ini, beban subsidi yang harus dibayarkan pemerintah akan berkurang. Penghematan subsidi ini salah satunya dialihkan ke sektor lain berupa Bantuan Langsung Tunai (BLT) atau disebut juga Bantuan Langsung Sementara Masyarakat (BLSM) bagi kelas menengah ke bawah.

Kenaikan harga BBM dan program kompensasi BLT ini banyak menimbulkan prokontra dari berbagai kalangan masyarakat dan pemerintah. Yang mana secara garis besar oleh digolongkan dalam dua alasan, yakni alasan ekonomi dan alasan sosial politik. Alasan Politik yang dikemukakan oleh Hasyim (2005) terdiri atas : untuk meningkatkan pendapatan negara karena subsidi membebani APBN, untuk melingdungi industri dalam negeri dalam rangka melawan kompetisi dari luar negeri, untuk mendukung daya saing barangbarang yang diekspor dengan barang-barang negara lain di arena perdagangan internasional, dan untuk menyesuaikan harga dengan perkembangan harga minyak dunia. Adapun alasan sosial politik meliputi untuk mengatasi persoalan polusi, melindungi masyarakat berpendapatan kecil dan pertimbangan politik saat ini. (Hasyim, 2005)

Sejalan dengan program tersebut, berdasar data dari Susenas Maret 2012-September 2012 yang menjadi landasan terkait sebagian hasil dari program kompensasi BBM tahun 2012. Jumlah penduduk miskin di Indonesia pada September 2012 mencapai 28,59 juta orang (11,66 persen), berkurang 0,54 juta orang dibandingkan dengan penduduk miskin pada Maret 2012 yang sebanyak 29,13 juta orang (11,96 persen).

Melihat realita tersebut dalam konteks urusan minyak, maka pemerintah pemegang kendali penting. Yakni Mengamankan pengadaan dan mengendalikan pemakaian minyak menjadi sentral kebijaksanaan pemerintah negara konsumen, sebaliknya jika negara eksportir berkeinginan memaksimalkan pendapatan devisa mereka demi tercapainya berbagai tujuan politik nasional, maka mengamankan sumber cadangan akan menjadi titik perhatian utama mereka. Akibatnya, masalah produksi ditribusi dan konsumsi minyak pasti mengundang intervensi dan pengaturan ketat pemerintah. (Qystein Noreng 1983)

Dibutuhkan adanya politik ekonomi harga minyak, yang mana wajib didampingi dengan adanya pola proteksi terhadap SDA, hasil produksi maupun kekayaan non materiil lainnya dari suatu bangsa sebagai pilar independensi. Bagi Indonesia dengan sistem ekonomi khasnya yakni ekonomi kerakyatan (walau aplikasinya dipertanyakan), maka yang lebih penting dalam pembangunan Nasional adalah mewujudkan ketahanan nasional yang kuat dengan lebih mengandalkan kekuatan dan ketahan ekonomi rakyat bukan segelintir pemilik modal. Jika dalam krisis ekonomi yang kini masih berlangsung ekonomi rakyat terbukti tahan banting dan banyak yang justru dapat lebih berkembang, maka jika kita berhasil memberdayakan, ketahanan ekonomi nasional akan lebih kuat dan lebih tangguh lagi di masa depan. (Mubyarto,2010)

Oleh sebab itu, dalam rangka menakar apakah kebijakan kenaikan BBM dengan paket kompensasi BBM apakah sudah setara dan harga yang muncul sebagai harga hasil penyunatan subsisi BBM sudah adil dalam rangka mewujudkan kesejahteraan masyarakat. Sebagai pisau analisanya, paper ini mengambil konsep keadilan ekonomi dari salah satu pemikir ekonomi Islam fase kedua yakni Ibnu Taimiyah.

\section{Siapa dan Mengapa Harus Ibnu Taimiyah?}

Sejarah hidup Ibnu Taimiyah (12631328) ditandai dengan terjadinya pergolakan politik dan sosial. Harran sebagai tempat kelahirannya merupakan salah satu wilayah yang menjadi sasaran pasukan Tar-tar, sehingga mengharuskan keluarganya mengungsi ke Damaskus. Sejak saat itu, keluarganya banyak belajar tentang masyarakat dan berusaha mengejar ilmu pengetahuan dan akademik. (Dr.A.A. Islahi, 1997)

Ibnu Taimiyah bukanlah tergolong seorang teoritisi murni, juga bukan ahli sejarah 
ekonomi murni. Sikapnya lebih seperti seorang dokter praktek, yang mencoba menyelidiki dan melihat penyakitnya, memberikan resep untuk mengobati sakitnya dan memberikan aturan tertentu demi perkembangan kesehatannya. Regulasi harga merupakan salah satu contoh resep yang diramunya.(Islahi AA, 1997). Bagian dari daur hidupnya mesti dilalui dalam penjara karena sikap kerasnya menentang pemerintahan yang dipandang tidak segaris dengan ajaran al-Qur'an. Fatwa-fatwa yang dikeluarkan juga sering bertabrakan dengan kebijakan penguasa. Ketegaran pribadinya memang tertopang dengan mitivasi untuk meluruskan umat Islam dari perilaku yang menyimpang dari ajaran. Oleh karenanya, sepak terjang yang diwariskan kemudian lebih dikenal dengan gerakan purifikasi reformatif. (Khalid Ibrahim Jindan,1994)

Dalam transaksi ekonomi, fokus perhatian Ibnu Taimiyah tertuju pada keadilan yang hanya terwujud jika semua akad berdasarkan pada kesediaan menyepakati dari semua pihak, dan didasarkan pula pada informasi yang memadai. Ketika berbagai aturan itu ditaati, harga pasar yang terjadi adalah wajar dan adil dengan syarat tidak adanya pasokan yang ditahan untuk menaikkan harga. (Karim, Adiwarman, 2010).

Dalam pandangan Ibnu Taimiyah, ada kebutuhan pokok manusia seperti pangan, sandang, papan dan sebagainya yang harus dipenuhi dan negara bertanggungjawab untuk mengatur kebutuhan mereka. Dalam kaitan ini, penetapan harga oleh pemerintah adalah baik. Tetapi, hak itu tidak bersifat absolut. Sebab, seperti diketahui oleh Ibnu Taimiyah, sebenarnya harga itu ditetapkan melalui kekuatan permintaan dan penawaran. Hanya dalam kasus dimana harga naik karena terjadinya katidakadilan atau ketidaksempurnaan mekanisme pasar disebabkan oleh ulah penjual, maka pemerintah boleh ikut campur dalam penetapan harga. Pun juga menyadari dampak negatif dari dari regulasi harga. Karena sebaiknya untuk mewujudkan gagasan itu, dibentuk sebuah dewan sebagai wadah mewakili kepentingan penjual dan pembeli, sehingga mereka bisa berdagang dengan sepenuh hati dan kemungkinan munculnya pasar gelap atau penyembunyian barang, bisa dihilangkan. Dalam kondisi serupa atau seperti itu, kini, dianjurkan diadakannya pengawasan atas peningkatan harga. (Islahi AA,1997)

Namun, yang menjadi pisau analisis pemikiran Ibnu Taimiyah dalam mencandra Kenaikan harga BBM dan Kompensasinya dari kacamata konsep keadilan sosial ekonominya yang spesifik tentang Harga yang adil dan kompensasi yang setara.

Penelitian-penelitian yang sudah ada lebih pada tataran aplikasi dari adanya dampak kenaikan harga BBM serta kritisisasi dalam penyaluran kompensasi BBM yang digaungkan oleh pemerintah. Melalui data sekunder paper ini akan mencoba menganalisis kadar keadilan pemerintah dalam aplikasi kompensasi dan harga yang setara dan adil.

\section{METODE PENELITIAN}

Metode penelitian adalah suatu prosedur atau cara untuk mengetahui sesuatu yang akan diteliti dengan langkah-langkah yang sistematis. Dalam penelitian ini, penulis menggunakan metode sebagai berikut ; Jenis penelitian ini adalah deskriptif kualitatif yaitu penelitian yang menghasilkan data deskriptif berupa kata-kata tertulis atau lisan dari orang-orang dan prilaku yang dapat diamati (Sugiyono, 2007). Adapun Pendekatan penelitian yang digunakan dalam penelitian ini adalah pendekatan fenomenologis, yaitu suatu penelitian yang ditujukan untuk mendeskripsikan dan menganalisis fenomena, peristiwa, aktivitas sosial, sikap, kepercayaan, persepsi, pemikiran orang secara individual maupun kelompok. (Sukmadinata, 2007). Berdasarkan pendekatan ini, penelitian ini bertujuan mengungkapkan fenomena sosial yang menyangkut tentang kenaikan harga BBM tahun 2013.

Penelitian ini dilakukan untuk menganalisis kebijakan yang ada, suatu analisis deskriptif yaitu, bagaimana menjelaskan kebijakan Kenaikan hargta BBM dan perkembangannya. Pengumpulan data dilakukan dengan observasi, dan dokumentasi. Analisa data bersifat kualitatif melalui tiga tahap: data reduction, data display, dan conclusion drawing/verification (Miles \& Hubermen, 1984). Dengan melalui tiga tahap 
kerja itu ingin mengungkapkan keadilan social ekonomi atas kebijakan kenaikan harga BBM dengan menggunakan konsep keadilan social ekonomi Ibnu Taimiyah.

\section{PEMBAHASAN DAN HASIL}

Analisa Harga Kenaikan BBM dengan Kompensasi BBM

Sebagai bahan pijakan awal menganalisa terkait kenaikan harga BBM dengan kompensasi BBM tentu dirunut dari pendapatan negara secara keseluruhan. Perkembangan realisasi pendapatan negara sangat dipengaruhi oleh perkembangan kondisi perekonomian, baik secara global maupun domestik. Indikator yang mempengaruhi pendapatan negara adalah pertumbuhan ekonomi, inflasi, nilai tukar, harga minyak mentah Indonesia (ICP), serta lifting minyak bumi dan gas alam, selain itu kebijakan pemerintah yang mempengaruhi proyeksi pendapatan negara yang dapat dicapai pada tahun 2013. Yang didiagnosa pertama kali untuk mengetahui terkait penggemblungan integrasi dana pendapatan negara, terutama pada sektor bukan pajak. Karena yang menjadi titik sasaran adalah terkait ke-equilibriuman penghasilan dengan pengeluaran negara dalam hal migas.

Penerimaan Negara dari Pajak Migas pada RAPBN 2013 mengalami penurunan terhitung Rp 619,8 miliar (0,9\%0 dibanding APBN 2013, karena lifting harga minyak dari $900 \mathrm{rb}$ barel perhari menjadi 840 ribu barel per hari. Sementara total penerimaan dari semua sumber pajak mengalami penurunan mencapai Rp 139.348,3 miliar turun 4,5\% dibandingkan
APBN 2013, hal ini disebabkan pertumbuhan ekonomi yang lambat menyebabkan pendapatan nasional secara menyeluruh menurun.

Sebab lain yang tidak kalah pentingnya yang mempengaruhi PNBP adalah melemahnya nilai tukar rupiah terhadap dolar AS. Peningkatan beban subsidi BBM tersebut, pada akhirnya menyebabkan peningkatan rasio defisit anggaran terhadap PDB dalam tahun 2013. Peningkatan defisit tersebut berpotensi menyebabkan terganggunya pencapaian keberlanjutan fiskal (fiscal sustainability).

Untuk mengamankan pelaksanaan APBN tahun 2013, bauran kebijakan yang diambil Pemerintah di bidang belanja pemerintah pusat, antara lain meliputi: (1) kebijakan pengendalian subsidi BBM; (2) pelaksanaan P4S; (3) pemberian bantuan langsung sementara masyarakat (BLSM); (4) pemotongan anggaran belanja $\mathrm{K} / \mathrm{L}$ secara terukur dan terstruktur; (5) pengalokasian anggaran untuk program pembangunan infrastruktur; dan (6) penambahan anggaran untuk persiapan Pemilu (melalui Badan Pengawas Pemilu).

Yang akan diuraikan dari data di atas fokus pada anggaran belanja subsidi dalam RAPBNP tahun 2013 diperkirakan mencapai sebesar Rp358.184,4 miliar. Jumlah itu menunjukkan kenaikan sebesar Rp40.965,8 miliar, atau 12,9 persen bila dibandingkan dengan alokasinya yang ditetapkan dalam APBN tahun 2013 sebesar Rp317.218,6 miliar.

Perubahan besaran subsidi tersebut disebabkan oleh beberapa faktor, antara lain:

Tabel 1.1. Belanja Pemerintah Pusat, 2012-2013 (miliar rupiah)

\begin{tabular}{|c|c|c|c|c|c|}
\hline \multirow{3}{*}{ Uraian } & \multirow{3}{*}{$\begin{array}{c}2012 \\
\text { LKPP Unaudited }\end{array}$} & \multicolumn{4}{|c|}{2013} \\
\hline & & \multirow{2}{*}{ APBN } & \multirow{2}{*}{ APBNP } & \multicolumn{2}{|c|}{ Perubahan } \\
\hline & & & & Nominal & $\%$ \\
\hline 1. Belanja Pegawai & $197.865,20$ & $241.606,30$ & $240.192,90$ & $(1.413,40)$ & $(0,6)$ \\
\hline 2. Belanja Barang & $140.913,50$ & $200.735,20$ & $190.644,70$ & $(10.090,50)$ & (5) \\
\hline 3. Belanja Modal & $143.674,10$ & $184.363,50$ & $187.010,20$ & $2.646,70$ & 1,4 \\
\hline 4. Pembayaran Bunga Utang & $100.510,00$ & $113.243,80$ & $112.901,20$ & $(342,6)$ & $(0,3)$ \\
\hline 5. Subsidi & $346.420,40$ & $317.218,60$ & $358.184,40$ & $40.965,8$ & 12,9 \\
\hline 6. Belanja Hibah & 75,9 & $3.621,30$ & $2.346,50$ & $(1.274,80)$ & $(35,2)$ \\
\hline 7. Bantuan Sosial & $75.628,77$ & $3.608,80$ & $71.315,90$ & $(2.292,90)$ & $(3,1)$ \\
\hline 8. Belanja Lain-lain & $4.073,10$ & $19.983,40$ & $30.699,4$ & $10.715,90$ & 53,6 \\
\hline Jumlah & $1.009 .160,9$ & $1.154 .380,9$ & 1.193.295,20 & $38.914,30$ & \\
\hline
\end{tabular}

Sumber: Kementerian Keuangan 
1. Perubahan subsidi BBM dan LPG tabung $3 \mathrm{~kg}$, serta subsidi listrik akibat perubahan harga minyak mentah Indonesia (ICP) dan nilai tukar rupiah terhadap dolar AS;

2. Perubahan volume konsumsi BBM bersubsidi;

3. Perubahan bauran energi (fuel mix);

4. Tambahan pembayaran kekurangan subsidi listrik, subsidi pupuk dan subsidi BBM tahun 2010-2012;

5. Penambahan durasi penyaluran raskin dari 12 bulan menjadi 15 bulan;

6. Perubahan anggaran subsidi pajak.

Subsidi BBM dan LPG tabung $3 \mathrm{~kg}$ dalam RAPBNP 2013 diperkirakan mencapai Rp209.915,4 miliar, yang berarti Rp16.110,1 miliar atau 8,3 persen lebih tinggi dibandingkan dengan pagunya dalam APBN tahun 2013 sebesar Rp193.805,2 miliar. Peningkatan tersebut disebabkan oleh:

a. perubahan harga minyak mentah Indonesia (ICP) dan melemahnya nilai tukar rupiah terhadap dolar AS;

b. pembayaran kekurangan subsidi BBM tahun 2010 (audited) sebesar Rp32,2 juta, dan tahun 2011 (audited) sebesar Rp4.029,7 miliar, serta perkiraan kekurangan pembayaran tahun 2012 sebesar Rp18.846,7 miliar;

c. perubahan volume konsumsi BBM bersubsidi yang diperkirakan mencapai 48,0 juta kiloliter dari pagu APBN tahun 2013 sebesar 46,0 juta kiloliter.

Selanjutnya, kebutuhan belanja subsidi BBM tersebut telah memperhitungkan langkahlangkah kebijakan pengendalian beban subsidi BBM tahun 2013, antara lain berupa:

1. Penyesuaian harga BBM bersubsidi khususnya jenis premium dan minyak solar;

2. Pengendalian konsumsi BBM bersubsidi secara bertahap melalui: (a) optimalisasi program konversi minyak tanah ke LPG tabung $3 \mathrm{~kg}$; (b) konversi BBM ke bahan bakar gas (BBG); (c) peningkatan pemanfaatan energi alternatif seperti bahan bakar nabati (BBN) dan BBG; (d) melanjutkan pelaksanaan pentahapan pembatasan penggunaan BBM bersubsidi; dan (e) penyempurnaan regulasi kebijakan subsidi BBM dan LPG tabung $3 \mathrm{~kg}$.

Anggaran belanja bantuan sosial dalam RAPBNP tahun 2013 direncanakan sebesar Rp71.315,9 miliar. Jumlah tersebut menunjukkan penurunan sebesar Rp2.292,9 miliar, atau 3,1 persen dari alokasinya dalam APBN tahun 2013 sebesar Rp73.608,8 miliar. Lebih rendahnya alokasi anggaran bantuan sosial tersebut, terutama dikarenakan adanya kebijakan pemotongan anggaran bantuan sosial, antara lain melalui:

1. pemotongan anggaran belanja bantuan sosial K/L sebesar Rp9.055,0 miliar;

2. pemotongan dana cadangan penanggulangan bencana alam sebesar Rp1.500,0 miliar.

Dalam alokasi belanja bantuan sosial tersebut, juga terdapat realokasi dana cadangan penanggulangan bencana alam dari BA BUN ke BA BNPB sebesar Rp200,0 miliar untuk tambahan dana on-call tahun 2013. Namun demikian, di sisi lain pemerintah menambah alokasi bantuan sosial untuk masyarakat miskin melalui P4S, yang dimaksudkan untuk menjaga daya beli masyarakat miskin sebagai dampak kebijakan pengendalian subsidi BBM melalui program-program perlindungan sosial yang ada, yaitu PKH, BSM, termasuk Beasiswa Bidik Misi. Program-program ini harus dilaksanakan secara tepat waktu, tepat jumlah, tepat sasaran, dan tepat biaya.

Anggaran belanja lain-lain dalam RAPBNP tahun 2013 direncanakan sebesar Rp30.699,4 miliar. Jumlah alokasi ini meningkat sebesar Rp10.716,0 miliar, atau 53,6 persen jika dibandingkan dengan pagunya yang ditetapkan dalam APBN tahun 2013 sebesar Rp19.983,4 miliar. Meningkatnya alokasi anggaran belanja lain-lain dalam RAPBNP tahun 2013 disebabkan antara lain:

1. dialokasikannya anggaran BLSM sebesar Rp11.625,0 miliar, sebagai bagian dari mitigasi dampak negatif kebijakan pengendalian subsidi BBM;

2. digesernya anggaran fee pelayanan Bank/ Pos Persepsi ke BA Kementerian Keuangan (BA 015) sebesar Rp208,5 miliar dan cadangan keperluan mendesak sebesar Rp685,4 miliar ke beberapa BA K/L; 
3. dialokasikannya cadangan anggaran Bawaslu untuk persiapan tahapan penyelenggaraan Pemilu tahun 2014 sebesar Rp500,0 miliar; dan

4. tidak dialokasikannya cadangan risiko perubahan asumsi ekonomi makro, yang semula dalam APBN tahun 2013 dicadangkan sebesar Rp3.000,0 miliar.

\section{Analisis Konsepsi Keadilan Sosial Ekonomi Ibnu Taimiyah}

Ada dua terma dalam salah satu bagian dari konsepsi keadilan sosial ekonomi Ibnu Taimiyah tentang masalah harga, yakni Kompensasi yang setara ('iwad al-mithl) dan harga yang setara (thaman al-mithl). Menurut dia, kompensasi yang setara kan diukur dan ditaksir oleh hal-hal yang setara dan itulah esensi dari keadilan (nafs al-'adl). Dia mengklasifikasinkan dua jenis harga yakni : Harga yang tak adil dan terlarang serta harga yang adil dan disukai. Dia mempertimbangkan harga yang setara itu sebagai harga yang adil. Jadi, dua kata: "Adil" dan "setara", digunakan saling mengganti, adapun prosedurnya mengikuti.

Data pijakan dari Pendapatan negara secara total (pendapatan dalam negeri : pajak dan bukan pajak, serta pendapatan hibah) yang mengalami penurunan, terhitung Rp 1.488.325,50 miliar dalam RAPBN 2013 dari total alokasi dalam APBN 2013 sebesar Rp 1.529.673,10 miliar, sehingga nominal penurunannya $\operatorname{Rp} 41.347,70$ miliar atau 2,7\%.

Dialurkan mulai dari penerimaan pajak Migas pada RAPBN 2013 mengalami penurunan $\mathrm{Rp} 619,8$ miliar (0,9\%) diabding APBN 2013, karena lifting harga minyak dari 90 ribu barel per hari menjadi 840 ribu barel per hari. Sementara total penerimaan dari semua pos pajak mengalami penurunan mencapai Rp 139.348,3 miliar turun 4,5\% bila dibandingkan dengan target APBN 2013 karena pertumbuhan ekonomi yang lambat menyebabkan pendapatan Nasional secara menyeluruh ikut menurun.

Penerimaan Negara bukan pajak, dari penerimaan SDA meningkat mencapai $\mathrm{Rp}$ 201.706,1 miliar lebih tinggi Rp 4.501,2 miliar atau 2,3\% dari APBN 2013. Peningkatan tersebut tidak lepas dari intervensi kuat dari peningkatan penerimaan dari SDA Migas yang mencapai Rp 179.256,5 miliar, perubahannya
Rp 4.388,1 miliar atau 2,5\% dari APBN 2013. Sehingga total penerimaan bukan pajak meningkat mencapai Rp 344.493,5 miliar, yang mana perubahannya Rp 12.298,1 atau 3,7\% dari APBN 2013, karena PNBP Migas, laba BUMN dan PNBP lai-lain mengalami peningkatan. Sementara total belanja negara pun meningkat, hal ini teinfeksi dampak kombinasi perubahan asumsi dasar ekonomi makro dan respon kebijakan yang diambil pemerintah. Yang mana tiada lain lebih dititik beratkan untuk alokasi subsisi (mencapai Rp 358.184,4 miliar dari $\operatorname{Rp} 317.218,6$ miliar, sehingga selisih nominalnya $\mathrm{Rp} 40.965,8$ miliar). Terkait beban berat subsidi dikangkangi oleh Subsidi BBM dan tabung LPG $3 \mathrm{Kg}^{*}$ ). inilah yang menjadikan defisit APBN, dan kebijakan yang diambil berupa pemangkasan alokasi subsidi, dan dalam realisasinya subsidi BBM tersebut lebih dinikmati oleh kalangan menengah ke atas. Namun, jika subsidi itu dipangkas, maka otomatis harga BBM melonjak (di atas kemampuan rakyat kecil), akan memicu kenaikan harga-harga bahan pokok yang menjadi kebutuhan masyarakat.

Pada 10 Pebruari 1982, melalui harian Kompas, Ibrahim Hasyim menulis simpulan pembahasan dengan menyatakan bahwa semua jenis BBM yang disubsidi, peningkatan konsumsinya sangat pesat, terutama minyak solar dan diperkirakan solar akan menjadi jumlah yang terbesar menggantikan posisi minyak tanah sebelumnya. Perkiraan itu sudah menjadi kenyataan sekarang ini. (Ibrahim Hasyim,2000) Artinya semakin gencar subsidi itu digelontorkan, maka semakin gencar pula konsumsi BBM masyarakat, terutama golongan menengah ke atas (pemilik kendaraan bermotor yang lebih dari satu), sementara bagi mereka golongan bawah, tidak lebih dari seperempatnya, karena fokusnya pada pemenuhan kebutuhan pokok (sandang, pangan dan papan).

Dilema ekonomi inilah yang mengharuskan pemerintah bersikap bijak dan mendisiplinkan pembelanjaan negara supaya tidak 'besar pasak daripada tiang', artinya ritinitas defisit APBN bisa diminimalisir bahkan ditangani. Sementara, logika ekonomi yang dipakai pemerintah adalah dengan menaikkan harga BBM dan di saat yang 
bersamaan pemerintah memberikan asupan dana melalui paket kompensasi BBM. Sekarang yang perlu dianalisa adalah, sudah setarakah kadar kompensasi yang diberikan pemerintah dengan kesengsaraan rakyat kecil dengan kebijakan kenaikan harga BBM (penyunatan subsidi BBM).

\section{Kompensasi yang Setara dan Harga yang Adil}

Kompensasi yang setara menurut Ibnu Taimiyah, bahwa ukuran setara ditilik dari segi kuantitas dari obyek khusus dalam penggunaan secara umum dan masih berkaitan dengan nilai dasar dan kebiasaan. Artinya dengan kenaikan harga BBM antara Rp 1,500,sampai Rp 2000,- . Yang mana dengan posisi pendapatan tetap. Adapun paket kompensasi BBM sebagai ganti rugi kebijakan kenaikan harga BBM dan menyebabkan kenaikan hargaharga bahan pokok dan sebagainya untuk meringankan beban rakyat kecil. Diantaranya: Raskin, BLSM, PKH, BSM dan perbaikan infrastruktur, bantuan sosial kesehatan dan sebagainya.

Bantuan Langsung Sementara Masyarakat (BLSM) berupa dana tunai yang akan dibagikan secara bertahap pada 2013 ini. Penerima bantuan ini adalah 15,5 juta rumah tangga yang mencakup 25\% rumah tangga dengan tingkat sosial ekonomi terendah di Indonesia. Penentuan 25\% rumah tangga ini berlangsung secara obyektif, berdasarkan pada Basis Data Terpadu hasil survei Pendataan Program Perlindungan Sosial (PPLS) 2011 yang berlangsung Juli hingga Desember 2011. Pelaksana surveinya BPS, bekerjasama dengan Tim Nasional Percepatan Penanggulangan Kemiskinan (TNP2K) yang diketuai Wakil Presiden RI (PPLS 2011 menghasilkan data komprehensif dan detail berupa daftar nama $40 \%$ rumah tangga berpenghasilan terendah di Indonesia, lengkap dengan alamat lengkapnya. PPLS 2011 menghasilkan data yang lebih baik dari survei sebelumnya karena menggunakan hasil Sensus Penduduk 2010 sebagai informasi awal mengenai penghasilan sebuah rumah tangga. Berikutnya, petugas PPLS 2011 melakukan konsultasi dengan rumah tangga miskin yang dapat memberikan informasi tambahan mengenai rumah tangga miskin di sekitarnya yang belum tercakup dalam data awal. Petugas survei juga melakukan observasi langsung di lapangan sebelum proses survei dan pengumpulan data berlangsung. Jika tak ada pembagian BLSM, rencananya data hasil PPLS 2011 akan dipakai sebagai dasar pelaksanaan berbagai program percepatan penanggulangan kemiskinan. Jadi, data hasil PPLS 2011 bukanlah hasil survei yang terburuburu dan khusus dibuat untuk membagikan BLSM. Data ini lebih baik kualitasnya daripada data yang dipakai untuk pembagian Bantuan Langsung Tunai (BLT) pada 2005 dan 2008 lalu).

Terkait dengan program BLSM, latar belakang pengalokasian anggaran dimaksud adalah dalam rangka mempertahankan tingkat konsumsi rumah tangga miskin dan rentan dari kemungkinan kenaikan berbagai harga kebutuhan dasar akibat adanya kebijakan penyesuaian harga BBM bersubsidi. BLSM juga bertujuan untuk mencegah penurunan tingkat kesejahteraan masyarakat miskin dan rentan akibat gejolak ekonomi yang mungkin terjadi seperti penjualan aset, berhenti sekolah, dan sebagainya. BLSM diberikan kepada 15,5 juta RTSM sebesar Rp150 ribu per bulan selama 5 bulan. Kenapa muncul angka Rp 150.000,- itu melalui proses perhitungan ekonometri dan tidak dipungkiri pula ada unsur politisasi, yang pasti nominal tersebut di-optimisasi sebagai angka penyeimbang dan penyelamat sementara dengan kenaikan harga BBM. Karena definisi kompensasi hanya sebagai ganti rugi atas kebijakan yang 'mengagetkan' untu ekonomi kecil, sehingga sebagai stimulus awal agar menyesuaikan dengan harga baru yang memang sifatnya sementara. Hal ini selaras dengan konsep kompensasinya Ibnu Taimiyah, bahwa kompensasi yang setara itu relatif merupakan fenomena yang pada akhirnya membentuk kebiasaan, dan ini yang membedakan dengan harga yang setara, karena patokannya pada jangka waktu serta fakto-faktor yang mempengaruhinya. Selanjutnya Ibnu Taimiyah Ibnu Taimiyah pun menggunakan term Kompensasi yang setara untuk permulaan dan harga yang setara untuk selanjutnya.

Kompensasi yang setara adalah kuantitas dari obyek khusus dalam penggunaan secara umum yang masih berkaitan dengan nilai dasar dan kebiasaan. Kita Candra dalam Penambahan 
jatah beras dalam program Beras untuk Rakyat Miskin (Raskin). Untuk tiga bulan selama tahun 2013, jatah Raskin naik dari 15 kilogram menjadi 30 kilogram. Harga tebusnya tetap Rp 1.600 per kilogram. Hal ini menitik beratkan pada kuantitas pada obyek yang disetarakan sebagai titik tumpu menuju keadilan. Yang mana dengan kenaikan harga BBM mengintervensi harga-harga bahan pokok ikut melonjak, yang tentu saja korban utamanya adalah masyarakat kecil, karena otomatis kebutuhan utama mereka adalah bahan pokok (makanan utama). Berikutnya, dalam salah satu paket kompensasi Pendidikan, yangma kadar dari tiap tingkat dibedakan sesuao kebutuhan di setiap level pendidikan (proporsional). Yakni paket kompensasi Tambahan jumlah bantuan pada program Bantuan Siswa Miskin (BSM) untuk setiap jenjang dengan rincian sebagai berikut:

Tabel 1. Bantuan Siswa Miskin Setiap Jenjang

\begin{tabular}{lcr}
\hline \multicolumn{1}{c}{ Jenjang } & BSM 2012 & \multicolumn{1}{c}{ BSM 2013 } \\
\hline SD/MI & $R p 360.000$ & $R p 450.000$ \\
SMP/MTs & $R p 550.000$ & $R p 750.000$ \\
SMA/MA & $R p 780.000$ & $R p 1.000 .000$ \\
\hline
\end{tabular}

Selain itu, setiap penerima bantuan siswa miskin akan mendapatkan tambahan Rp 200.000 untuk tambahan biaya seragam, atau alat tulis sekolah. Tambahan ini hanya diberikan sekali saja pada 2013 ini. Tak hanya menambah nilai bantuan, Pemerintah juga memperluas cakupan penerima BSM. Jika tahun lalu BSM hanya menjangkau 8,7 juta siswa, tahun ini BSM akan mengalir untuk 16,6 juta siswa.

Kemudian konsep kompensasi yang setara dijelaskan oleh Ibnu Taimiyah dialokasikan juga sebagai konsep moral dan konsep hukum. Karena sebagai konsekuensi logis atas kebijakan menaikkan harga BBM, maka agar menghindari kelesuan pasar karena kemampuan Willings To Pay (WTP) dari masyarakat menurun yang berefek pada kelesuan sektor produksi, maka kompensasi yang diberikan sebagai penyeimbang. Dengan nilai moralnya sebagai institusi pengayom rakyat (pemerintah). Yang tentu saja dalam kebijakan kompensasi yang setara ini unsur legal etiknya memang 'shahih'. Artinya kebijakan yang diambil dengan penuh kesadaran sebagai uaya stabilisasi perekonomian. Hal ini senada diungkapkan oleh Menkokesra RI Joko Laksono (Sindo, 07/05/2013), "saat ini jumlah masyarakat miskin masih di atas 11,66 persen. Jika mereka tidak diberikan kompensasi maka dikhawatirkan jumlahnya akan melonjak pesat menjadi di atas 12-13 persen. Hal ini dikarenkan, inflasi akan semakin meningkat dan daya beli masyarakat rendah." Lebih jelasnya bisa teraplikasi dalam Untuk menambah lapangan kerja dan memperbaiki kualitas hidup masyarakat miskin, Pemerintah menyiapkan dana Rp 6 triliun untuk perbaikan dan pembangunan infrastruktur dasar. Selain menyentuh infrastruktur dasar seperti irigasi dan jalan-jalan desa, program ini juga mencakup pembangunan dan penyediaan fasilitas ke air bersih di desa-desa nelayan maupun kawasan rawan air.

Satu hal lagi yang menggelitik, jika dari kacamata kompensasi ada unsur moral dan legal hukum, maka dalam fenomena pemerintahan kita, ketika selalu digaungkan defisit anggaran karena subsidi yang menggelembung. Secara logika ekonomi bisa diterima, namun jika hal itu tidak tercermin dalam sikap para pemimpin bangsa (anggota DPR maupun pejabat pemerintah) dalam kehidupan seharai-hari yang mengurangi gaya hidup mewahnya. Masih ingat dalam benak kita tentang isu kenaikan gaji presiden dan PNS, kemudia pembangunan gedung DPR serta tambahan fasilitas mobil dinas pejabat. Hal tersebut menjadi point ketidakadilan kompensasi secara moral, sementara rakyatya untuk mkan harus rela menunggu raskin yang terkadang tidak layak untuk dimakan, maupun rela berdesak-desakan di angkot demi menghemat BBM. Secara legal, dalam UUD 1945 pasal 27 (ayat 2), pasal 31, pasal 33 dan pasal 34 sudah jelas mengamanahkan kepada pemerintah untuk memberikan kompensasi yang setara dan adil kepada mereka yang tunawisma, divable, tunaharta, tunailmu yang bukan alasan disengaja, maka dalam point kompensasi sebagai konsep moral dan etik menurut kami kompensasi belum terlampaui.

Lebih lanjut, Dia berkata : "Mengkompensaikan suatu barang dengan yang lain yang setara merupakan kewajiban yang berlaku adil ('adl wajib) dan bila 
pembayarannya secara sukarela dinaikkan, itu lebih baik dan merupakan perbuatan baik yang sangat diharapkan (ihsan mustahabb). Tetapi sebaliknya, mengurangi kuantitas dari nilai kompensasi sangat dilarang dan merupakan ketidakadilan (dzulm muharram). Demikian juga mengganti barang yang cacat dengan yang setara merupakan keadilan yang diperbolehkan ('adl ja'iz). Meningkatkan kerusakannya justru melanggar hukum (muharram), sedang mengurangi kerusakan merupakan kebaikan yang dianjurkan (ihsan mustahab). Hal ini bisa dilihat dalam Tambahan dana bantuan untuk peserta Program Keluarga Harapan (PKH) dari Rp 1.390.000 per tahun menjadi Rp 1.800.000 per tahun. Lewat PKH, Pemerintah membagikan dana tunai bagi keluarga-keluarga termiskin. Sasarannya 2,4 juta keluarga. Pemerintah mengusulkan kepada DPR, mulai 2013 setiap keluarga mendapat dana tunai Rp 1.800.000 per tahun. Ini lebih besar daripada pembagian tahun lalu sebesar Rp 1.390.000 per tahun. Namun, pembagian dana tunai itu ada syaratnya. Misalnya, keluarga termiskin itu harus rajin ke Puskesmas untuk memeriksakan kesehatan. Jika memiliki anak usia sekolah, keluarga itu harus menyekolahkan anaknya. Kehadiran anak di sekolah dipantau dan menjadi bagian dari persyaratan untuk memperoleh dana tunai. Secara otomatis, anak-anak dari rumah tangga peserta PKH juga akan mendapatkan Bantuan Siswa Miskin (BSM). Peserta PKH juga mendapat perlindungan Jaminan Kesehatan untuk Masyarakat (Jamkesmas).

\section{Mekanisme Pasar}

Berikutnya tentang Mekanisme Pasar, Ibnu Taimiyah mengatakan bahwa naik turunnya harga tidak selalu berkaitan dengan kezaliman (zulm) yang dilakukan seseroang. Sesekali alasannya adalah adanya kekurangan dalam produksi atau penurunan impor dari barang-barang yang diminta. Adapun menurutnya yang mempengaruhi naik turunyya permintaan adalah selera atau keinginan, sedangkan faktor pertimbangan dalam suplai (penawaran) adalah produksi lokal dan impor.

Hal tersebut menunjukkan bahwa ketika terjadi kelebihan permintaan dan pada harga yang sama dan kekuangan penyediaan barang (suplai) pada harga yang sama atau sebaliknya, kekurangan permintaan dan kelebihan suplai pada harga yang sama, akhirnya akan mendorong penurunan harga, maupun permintaan meningkat sementara tidak diimbangi dengan penyediaan yang mumpuni maka harga akan nampak (naik). (Islahi, 1997) Hal ini yang terjadi dalam kasus naiknya harga BBM, berdasar data di atas, bahwa konsumsi BBM di negara kita semakin hari semakin meningkat, sementara BBM (migas) sebagai SDA unrenewable sehingga tidak disalahkan jika harganya kian hari kian melonjak.

Dalam salah satu bukunya fatawa, Ibnu Taimiyah mencatat beberapa faktor yang berpengaruh terhadap permintaan dan konsekuensinya terhadap harga, diantaranya : keinginan penduduk (al-raghbah) atas jenis berbeda dan selalu berubah-ubah, Jumlah peminta (tullab), Kondisi menguat atau melemahnya tingkat kebutuhan atas barang tersebut, Kualitas pelanggan (kondisi peminta), Bentuk alat pembayaran dalam jual beli, Tujuan dari kontrak adanya (timbal balik) pemilikan oleh kedua pihak (transaksi), Serta aplikasi yang sama pada orang yang meminjam atau menyewa.(Islahi, 1997)

Dan dalam konteks konsekuensi kenaikan harga BBM ada pada faktor keinginan (selera) yang mana masuk dalam hal daya konsumtifnya yang meningkat, sedangkan jumlah peminta pun menjadi alasan naiknya harga BBM dengan kapasitas terbatas sementara jumlah penduduk meningkat, pasti keinginan mengkonsumsi BBMnya pun semakin meningkat. Termasuk point kuat lemahnya permintaan komoditi tersebut, yang mana ini sejalan dengan pernyataan di atas bahwa komoditi migas memang strategis mengingat sumber energi yang dibutuhkan oleh semua orang di setiap negara, sedangkan terkait lat tukar sebagai penentu dapat dilihat pada kondisi floating exchange rate atau fixed exchange rate, yang mana mata uang di setiap negara harus dikurskan dengan mata uang luar negerinya, yakni dolar Amerika, dan ini pun menyebabkan harga BBM di Indonesia mahal karena harus disesuaikan dengan nilai tukarnya.

Industri minyak internasional mencerminkan adanya satu struktur 
organisasi pengendalian dan pemilikan yang "Oligopolistik", sebab ia didominir oleh sejumlah pemegang saham yang serba terbatas para jutawan-jutawan internasional dan bahkan pemerintah negara pemilik perusahaan minyak itu sendiri. Kepentingan-kepentingan politik jangka panjang yang mereka rumuskan selalu mempengaruhi kepentingan politik jangka pendek mereka. Singkatnya, antara perusahaan tersebut terjalin satu mekanisme kerja dan konsultasi reguler. Penentu dominan dalam percaturan bisnis minyak internasional dengan sendirinya terbatas pada sejumlah kecil perusahaan minyak raksasa dan pemerintah negara-negara terkemuka yang sekaligus berfungsi sebagai perumus kebijaksanaan jangka panjang.

Konsekuensinya, pola produksi, distribusi dan konsumsi minyak hanya mendapat tekanan pengaruh yang kecil sekali dari kekuatan mekanisme pasar dibandingkan dengan sejumlah besar komoditi jenis lain. Tegasnya, pertimbangan politik dan kepentingan jangka panjang lebih mewarnai kehidupan perminyakan baik di tingkat nasional maupun internasional sedang pemerintah negara tampil sebagai penentu dominan. (Qystein Noreng, 1983) Suatu dilema, ketika membiarkan harga masuk dalam mekanisme pasar yang dikendalikan oleh negara-negara bertangan dingin, atau negara-negara penguasa kapital, menyebabkan Indoensia negara kecil harus mengikuti aturan main, yang sedikit banyaknya tidak menguntungkan Indonesia. Oleh sebab itu, Ibnu Taimiyah memberikan batasan mekanisme pasar dengan konsep regulasi harga supaya tidak terjadi kedzaliman yang ditimpakan kepada masyarakat kecil.

\section{Regulasi Harga}

Termasuk di dalam konsepsi keadilan sosial dan ekonomi Ibnu Taimiyah dalah Regulasi Harga, yang mana hal ini sebagai lanjutan dari analisis tentang harga yang adil dan mekanisme pasar dengan menunjukkan kebijakan dini tentang kontrol harga oleh pemerintah. Yang mana tujuan dari regulasi harga adalah untuk memelihara kejujuran. Dalam regulasi harga, terdapat perbedaan pendapat tentang boleh tidaknya menetapkan harga. Namun Ibnu Taimiyah menggarisbawahi bahwa tidak boleh seorang pun menetapkan harga yang lebih tinggi maupun yang lebih rendah dari harga yang ada. Sebagaimana Rasullah pernah mencontohkannya dengan sikap penolakannya atas tawaran untuk menetapkan harga. Penetapan harga tersebut akan menghasilkan eksploitasi atas kebutuhan penduduk dan penetapan harga tersebut juga akan merugikan penjual. Dan yang diperbolehkan adalah pengaturan harga, sedangkan penetapan harga hanya diperbolehkan jika dalam keadaan darurat. (Islahi, 1997) Begitu juga dengan harga BBM ini, yang mana sejatinya perlu ada restrukturisasi atas penentuan harga migas. Sementara, di Indonesia pemerintah punya hak veto atas penetapan harganya, sehingga tidak disalahkan jika memang ada ketidakjujuran, ketidakpuasan maupun terksploitasinya rakyat kecil sehingga menurut Ibnu Taimiyah menyebabkan kerusakan harga. Namun lagilagi kembali pada sistem yang ada, Indonesia hanya bagian kecil dari negara-negara yang punya kendali atas sirkulasi pendanaan maupun perdagangan dunia. Dan hal itu mempengaruhi pula kebijakan politik dalam Negeri.

Jadi dari beberapa point konsepsi ekonomi Ibnu Taimiyah mengerucut pada keadilan sosial ekonomi masyarakat, karena kembali pada misi Ibnu Taimiyah bahwa mempurifikasi kebihupan manusia supaya sesuai dengan al-Qur'an dan Hadits, termasuk dalam hal ekonomi, sehingga mampu menciptakan masyarakat yang adil dan sejahtera.

\section{KESIMPULAN}

Berdasarkan data-data yang telah disajikan di atas, maka tidak ada yang salah dengan logika pemerintah untuk menaikkan harga BBM dengan menyunat subsidi BBM yang diganti dengan paket kompensasi. Secara kuantitatif sejalan dengan konsep kompensasi yang setara (secara obyek, kuantitas) Ibnu Taimiyah, sehingga mampu menunjukkan kondisi keadilan sosial ekonomi masyarakat.

Namun, jika ditilik dari konsepsi kompensasi yang setara (secara moral dan legal) dari kacamata Ibnu Taimiyah, maka segala bentuk kompensasi yang diberikan sebagai 'tumbal' pemerintah untuk meninabobokkan 
rakyat sangat tidak relevan. Dan menjauh dari misi mewujudkan keadilan sosial bagi masyarakat.

Sementara Mekanisme Pasar dan Regulasi harga yang diterapkan dalam kebijakan kenaikan harga BBM belum sepenuhnya menyatu dengan konsepsi ekonominya Ibnu Timiyah. Hal ini tidak lepas dari faktor sosio-historis sehingga menjadikan independensi Indonesia yang tidak dimunculkan. Padahal jika diaplikasikan secara masif, maka konsep ini akan berhubungan positif dengan konsepsi ekonomi kerakyatan yang lebih berorientasi pada kesejahteraan masyarakat (terutama rakyat kecil).

\section{REFERENSI}

Dzofir, Arif Maftuhin, 2004, Tugas Negara Menurut Islam, Yogyakarta : Pustaka Pelajar. Terjemahan dari Ibnu Taimiyah, 1985, Public Duties in Islam, The Institution of the Hisba, London: Yhe Islamic Foundation.

Hasyim, Ibrahim, 2000, Bunga Rampai : Subsidi BBM dari Dulu hingga Sekarang, Jakarta : Pertamina.

Hasyim, Ibrahim, 2009, 40 Tahun Bergelut Energi : BBM, Kapan Selesai?, Jakarta : Bintang Satu Publishing.

Inayati, Hani, 2006, Skripsi : Dampak Kenaikan Harga BBM Terhadap Pendapatan dan Pengeluaran Konsumsi Rumah Tangga Sopir Angkot serta Keuntungan Usaha Angkot di Kota Bobor (Studi Kasus Trayek 03 Jurusan Baranangsiang-Bubulak), FEM IPB : Departeman Ilmu Ekonomi.

Islahi, A.A., 1997, Konsepsi Ekonomi Ibnu Taimiyah, Surabaya : PT Bina Ilmu Offset.

Jindan, Khalid Ibrahim, 1994, Teori Pemerintahan Islam : Menurut Ibnu Taimiyah, Jakarta : PT Rineka Cipta.

Karim, Adiwarman, 2010, Sejarah Pemikiran Ekonomi Islam, Jakarta : Rajawali Pers.

Mubyarto dkk, 2005, Menggugat Ketimpangan dan Ketidakadilan Ekonomi Nasional: Mengurai benang kusut Subsidi BBM dan Defisit APBN, Yogyakarta : Aditya Media-PUSTEP UGM. Mubyarto, 2010, Membangun Sistem Ekonomi, Yogyakarta : BPFE-Yogyakarta, cet III.

Noreng, Qystein, 1983, Minyak dalam Politik : Upaya Mencapai Konsensus Internasional, Jakarta : CV Rajawali.

Nota Keuangan dan RAPBN-Perubahan Tahun Anggaran 2013, oleh Kemenkeu Republik Indonesia.

Puspitawati, Herien dkk, 2006, Dampak Subsidi Langsung Tunai (SLT)-BBM Pada Kesejahteraan Keluarga Miskin Di Kota dan Kabupaten Bogor-Jawa Barat, Kerjasama Departemen Ilmu Keluarga dan Konsumen (IKK) FEMA-IPB dengan Kementrian Pemberdayaan Perempuan RI.

Tim Sosialisasi Penyesuaian Subsidi Bahan Bakar Minyak, 2013, Bersama-sama Selanatkan Uang Bangsa. 